Journal of English Language Teaching and Applied Linguistics

ISSN: 2707-756X

DOI: $10.32996 /$ jeltal

Journal Homepage: www.al-kindipublisher.com/index.php/jeltal

JELTAL

\title{
The Use of L1 Metalanguage in L2 Classrooms: The Case for Arabic
}

\author{
Mehmet Bulent Rakab 8(D) \\ Community College of Qatar, Qatar \\ $\square$ Corresponding Author: Mehmet Bulent Rakab, E-mail: Mehmet.rakab@ccq.edu.qa
}

ARTICLE INFORMATION
Received: May 25, 2021
Accepted: June 18, 2021
Volume: 3
Issue: 7
DOI: $10.32996 /$ jeltal.2021.3.7.5

\section{KEYWORDS}

L1, L2, metalanguage, Arabic, discrepancy, beliefs,

\section{ABSTRACT}

With the rise of bilingual and multilingual approaches to teaching a second/foreign language, an overwhelming majority of second language acquisition (SLA) researchers have emphasized the important role of the use of mother tongue (L1) in a second language (L2) class and have argued that the use of $L 2$ positively contributes to the cognitive development of students. However, what aspect of $L 1$ should be used in an L2 class have not been specified explicitly. This study set out to investigate the extent to which teachers believe in the efficacy of the use of L1 metalanguage and the extent to which they use it in their classes in the English as a Foreign Language (EFL) context of Qatar. The second aim was to assess students' beliefs regarding the extent to which the use of L1 metalanguage in an L2 class facilitated their learning process. Most importantly, the study aimed to investigate whether there was a discrepancy between students' expectations and teachers' agendas regarding the use of L1 metalanguage in $\mathrm{L} 2$ classrooms. The hypothesis that underpinned this study was that the use of L1 metalanguage to explain structural concepts in L2 contributed to crosslinguistic and metalinguistic awareness. The study adopted a qualitative approach; two questionnaires were developed, one for students and one for teachers. The questionnaire consisted of 5-point Likert scale statements and questions. Twenty-six undergraduate students and eight teachers participated in the study. The students' proficiency level in English was elementary. The teachers were recruited on the basis of their native Arabic language proficiency. The findings suggested that both teachers and students viewed the use of Arabic in their English classes positively, and that no substantial discrepancy was observed between the students and the teachers over the issue of the use of Arabic in class. A minor discrepancy was that whereas the teachers were inclined to use Arabic slightly more for the teaching of grammar than the teaching of vocabulary, the students believed that the use of Arabic for learning vocabulary was more beneficial to their learning than it was for learning grammar.

\section{Introduction}

The use of L1 in L2 classes continues to be a controversial issue in SLA research. A fair amount of research has been conducted on the use of L1 in the L2 classroom. However, what aspects of L1 that should be part of an L2 class have not been identified and defined explicitly. Nazary (2008) notes that "when used appropriately [emphasis added], the use of L1 can be very beneficial" while Atkinson (1987), an advocate of bilingual approach to language teaching, suggests that L1 should be used "judiciously". The terms, "appropriately" and "judiciously" are somewhat vague in terms of what exactly they refer to, and hence, it is essential to specify what aspect of $L 1$ needs to be used in L2 classes. This study argues that the use of L1 metalanguage to explain structural concepts in L2 contributes to crosslinguistic and metalinguistic awareness. In doing so, the study aims to explore whether the use of L1 metalanguage in an L2 class could be beneficial to both teachers and students. In this sense, the study limits L1 use in L2 classes to the use of L1 metalanguage where teachers can make crosslinguistic references. Teachers can use L1 metalanguage not only for the teaching of grammar, but also for teaching vocabulary, phonology, and other formal properties of language such as syntax and morphology.

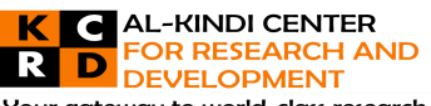

Your gateway to world-class research

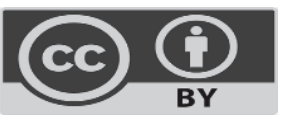

Published by Al-Kindi Center for Research and Development, United Kingdom. Copyright (c) the author(s). This open access article is distributed under a Creative Commons Attribution (CC-BY) 4.0 license 
The use of L1 metalanguage in an L2 class is indeed an area which SLA research has somewhat neglected. The objective of this study is twofold. The first goal is to assess the extent to which L2 teachers use L1 metalanguage in their class. The second goal is to investigate whether students' expectations and teachers' agendas correspond regarding the use of L1 metalanguage in L2 classrooms.

\section{Literature Review}

Motivated by Chomsky's Universal Grammar (1965) and Krashen's Input Hypothesis (1982), teachers with a training background in Communicative Language Teaching (CLT), in particular, have the tendency to avoid the use of L1 in L2 classrooms (Simard, 2004). Simard discusses the trend that has been dominating English as a Second Language (ESL) classrooms. She explains that especially in the 1970s and 1980s, the strong version of CLT was practiced in classrooms which tolerated no reference to L1 and explicit instruction especially in grammar. Later on, Focus on Form (Long, 1991) was integrated into CLT methodology which enabled some focus on language when there was a need. The emphasis in CLT was placed on expressing meaning, and the teaching of formal aspects of $\mathrm{L} 2$ was discouraged in the name of promoting communicative competence. As a result, metalanguage and references to learners' $\mathrm{L} 1$ became virtually absent from these classrooms because the use of $\mathrm{L} 1$ was regarded as an obstacle to L2 learning (Dabene \& Bourguignon, 1982, cited in Simard, 2004). Unfortunately, the term communicative has been used loosely by many researchers to refer solely to oral competence.

Hawkins (1999, p. 131) reacts critically to this conviction and explains the reasoning behind the avoidance of L1 use in class: "since all children acquire the spoken form of their mother tongue without intervention of the teaching or learning of grammar, why not simply expose them to the foreign language and let them acquire it naturally, thus imitating the child." A similar mindset existed more than a century ago. In 1880, Gouin (cited in Hawkins, 1999, p. 131) expressed his wishful thinking by saying that "learning a second language should be as natural as learning to fly is for the bird." Reaction to such an oversimplistic conviction came from Sweet (1899, cited in Hawkins, 1999, p. 131):

The fundamental objection to such a natural method is that it puts the adult into the position of an infant, which he is no longer capable of utilizing, and at the same time does not allow him to make use of his own special advantages.

In a similar vein, Tokowicz and MacWhinney (2005) argue:

When adults attempt to learn a new language, they start with an already established grammatical system, replete with well-articulated concepts and labels for those concepts. Unlike children, adults are able to transfer large segments of their $L 1$ over to the new $L 2$, and not all transfer from the $L 1$ to the $L 2$ is negative. (p. 175)

Cook (2001) and Zacharias (2004) point out that the use of L1 in an L2 class would hinder L2 acquisition was a commonly held belief, although this claim is rarely justified by solid research findings. There was also a widespread perception that the use of L1 in an L2 class should be minimized so that students could be exposed to more L2 input. Horst, White and Bell (2010, p. 331) point out that "a longstanding orthodoxy for language teachers trained in the communicative tradition has been to avoid all use of the learners' first language in class, or at least to use it as little as possible."

A natural consequence of this simplistic approach to language learning produced teachers who believed that all they needed to do was speak in the target language. After a while, the learner would somehow begin to use the language naturally, just like a child did when acquiring his mother tongue. It must be emphasized that such communication-first approaches to language teaching limit teaching to oral proficiency only, thereby excluding reading and writing skills. Mattingly (1972, cited in Hawkins, 1999, p. 132) points out that "there is not a scrap of evidence for any innate expectation regarding written language. Mastering reading and writing is learned, not an innately programmed process." This suggests that for reading and writing skills to be acquired, explicit language instruction is required.

Recent bilingual and multilingual research suggests that the use of native language in $\mathrm{L} 2$ classrooms yields consistently positive outcomes in language learning (Bialystok, 2009; Hammarberg, 2010; Horst, White \& Bell, 2010; Jessner, 2008). In fact, the "English only" dogma that has dominated the ESL field in both North America and the United Kingdom is fading, and is being replaced with bilingual and multilingual orientations to the teaching and learning of languages.

Advocates of bilingual approaches to language teaching discredit the monolingual approach from a few perspectives (Miles, 2004). The first one is that exposure to language input on its own does not suffice to make language learning complete. The second perspective argues that native teachers are not the best teachers and that a monolingual approach to teaching is 
impractical. The third perspective emphasizes that making comparisons between the mother tongue and the second language has a significant potential to promote metalinguistic awareness in students.

Similarly, Butzkamm (2003) maintains that "successful learners capitalize on the vast number of linguistic skills and world knowledge they have accumulated via the mother tongue [emphasis added]" (p. 31). Horst, White \& Bell (2010, p.333) also assert:

Regardless of the extent to which the language teacher avoids using the L1 in class, it is still always there in the minds of the learners. Since learners may draw on L1 resources anyway, why not do this overtly in class?

Studies of the bilingual lexicon suggest that learners' process $L 2$ input via links to $L 1$ form in the early stages of $L 2$ acquisition, which implies that L2 words are subconsciously translated into L1 (Horst, White \& Bell, 2010). According to Nation's (2003) "Balanced Approach", learners' L1 should be respected to make students feel that their L1 positively contributes to their learning and that it is by no means inferior to English. Horst, White and Bell (2010) argue that crosslinguistic awareness, which is one of the fundamental components of metalinguistic awareness, contributes to the acquisition of reading and writing skills.

A critical reaction comes from Laufer, Meara and Nation (2005, p. 6): "forget all the criticism you have heard about rote learning and translation; research has repeatedly shown that such learning is very effective." Furthermore, Nation (2003) suggests that the use of bilingual cards, L1-L2 word pairs and translation in L1 contribute to an increase in vocabulary size.

In addition, Cummins (1981) argues that solid initial literacy plays a key role in successful second language acquisition and in academic success. He adds that if students' L1 is promoted, it would contribute to their development of literacy skills in both their $\mathrm{L} 1$ and $\mathrm{L} 2$. This is particularly true for minority students who live in a society where English is the dominant language.

Auerbach (1993) emphasizes the important role that L1 plays in developing metacognitive awareness in composing texts. Likewise, Duff (1989) discusses the positive aspects of using translation as a language learning activity and argues that translation can help flexibility, accuracy, and clarity in language learning. Nazary (2008, p. 143) furthermore contends that "elementary learners who are not proficient enough to express themselves in $L 2$, must constantly think before they speak and this inner speech happens in L1."

In the ESL context of Spain, Garcia (1991) reports that lower grade teachers used both Spanish and English while higher grade teachers used mostly English. Garcia reports that the use of the L1 in the early stages of ESL acquisition is critical to later success and that a bilingual approach to language teaching facilitates the acquisition of English. Similarly, Butzkamm (2003, p. 36) posits that "with growing proficiency in the foreign language, the use of the mother tongue becomes largely redundant and the Foreign Language (FL) will stand on its own two feet." This indicates that students with higher proficiency levels tend not to need much L1 input compared to students with lower proficiency levels, who need more scaffolding, especially through L1. This points to a discrepancy between students with advanced proficiency levels in English and students with lower proficiency levels in terms of their attitudes towards the use of L1 in an L2 class. Prodromou's study (2002) revealed that students at higher proficiency levels had a negative attitude towards the use of $L 1$ in their classroom while students with lower proficiency levels expressed a greater need for the use of their mother tongue in class.

As for studies conducted on the beliefs and attitudes towards the use of L1 in L2 classes, Burden (2000) investigated the attitudes of undergraduate students and instructors towards the use of $L 1$ in the (EFL) context of Japan. The results revealed that both students and teachers had a positive attitude towards the use of Japanese in class, especially in terms of teaching vocabulary and grammar, giving instructions, clarifying issues regarding tests, confirming comprehension, and relaxing the students.

In the context of Spain, research conducted by Schweers (1999) indicated that approximately $89 \%$ of the students believed that the use of Spanish in class facilitated learning. Moreover, students wished that $39 \%$ of class time could be spent in their L1, which they thought would facilitate comprehension. Tang's research (2002) in the EFL context of China depicted similar results. The research conducted with 100 students and 20 teachers showed that some use of L1 in class assisted the teaching and learning process rather than depriving students of exposure to English. A large-scale study in the US also indicated that "despite the prevailing monolingual principle [emphasis added] in US FL classes, both the target language and the L1 appear to serve important functions" (Levine, 2003, p. 356). In another study, Stapa and Majid (2006) investigated the extent to which the use of L1 was effective in terms of generating ideas for writing in L2. It was found that those students who used their first language to generate ideas performed remarkably well in writing tasks; researchers attribute this to the fact that L1 promotes and triggers background knowledge for L2 tasks. 
As for students' knowledge of L2 metalanguage, Berry (1997) used a 50-item questionnaire to investigate the extent to which undergraduate students in Hong Kong knew grammatical terminology (metalanguage). The researcher also asked teachers whether they were able to predict the extent to which their students knew grammatical terminology. The findings portrayed a large discrepancy in terms of what the teachers thought their students knew about grammatical terminology and what the students actually did. It was evident that the teachers overestimated students' knowledge of grammatical terminology. The discrepancy between what students actually know and what their teachers believe they do is a promising avenue for further research in the domain of SLA. Previous research on teachers' expectations and on students' needs revealed a significant mismatch on topics such as grammar teaching and error correction (Schulz, 1996, 2001; Phipps \& Borg, 2009).

This study also investigated whether there was a discrepancy between students' linguistic needs and whether or not teachers were aware of their students' needs, especially in terms of L1 metalanguage use in an L2 class.

\subsection{Pedagogical perspectives}

The literature reviewed above suggests that students in general have a positive attitude towards the use of L1 in class. As Auerbach (1993, p. 18) puts it, "when the native language is used, practitioners, researchers, and learners consistently report positive results." The use of $\mathrm{L} 1$ facilitates comprehension and reduces their stress. Atkinson proposes the judicious use theory, according to which "L1 works as a vital source and also a communicative tool both for students and teachers" (p. 21).

Auerbach argues that a monolingual approach to language teaching may slow down the acquisition process. She also contends that the avoidance of $L 1$ in class prevents learners from tapping into their rich cognitive and linguistic $L 1$ resources. Rejecting the use of L1 denies students the right to critically reflect on their vast L1 resources, thereby imposing childlike uses of language on them and depriving them of the possibility of critical reflection (Auerbach, 1993). Simard (2004) explains that the language curriculum in Quebec, Canada recommended that teachers use a strong version of the communicative approach in their language classroom, where teachers avoided explicit language teaching strategies, let alone any reference to French, which was students' L1.

Zhang (1998) explains that learners can easily become sophisticated users of their pidginized communicative interlanguage, which is a linguistic system developed extensively through meaning-focused methodologies such as CLT. Zhang posits that such a pidginized version of the target language deviates from the academic and standard language norms and needs to be unlearned to start the acquisition process right from the beginning. Horst, White and Bell (2010, p. 347) lament: "sadly, in the case of language teaching this view has been so strongly discouraged that generations of teachers have become convinced that referring to the first language in the second language classroom is somehow detrimental."

To summarize the foregoing discussion, according to the methodological framework of CLT, the use of L1 in an L2 class was perceived to hinder or slow down the acquisition process. However, Zacharias (2004) points out that the argument that the use of L1 constitutes hindrance to L2 acquisition is not justified by research, which suggests that the avoidance of L1 is solely based on belief.

\subsection{Ideological Aspects of the Avoidance of $L 1$}

Auerbach (1993, p.1) argues that "the issue of language choice is intimately linked with issues of power." She asserts that the exclusive use of $L 2$ reflects a particular ideological perspective, that it is based on unexamined assumptions, and that it contributes to the reinforcement of existing inequities in our societies. Auerbach argues that "authority and power are manifested by institutional practices around language use" (1993, p. 11). According to Auerbach (1993, p. 15 ), "the rationale used to justify English only in the classroom is neither conclusive nor pedagogically sound". Collingham (1988) along similar lines argues:

To treat adult learners as if they know nothing of language is to accept the imbalance of power and so ultimately to collude with institutional racism; to adopt a bilingual approach and to value the knowledge that learners already have is to begin to challenge that unequal power relationship and, one hopes, thereby enable learners to acquire the skills and confidence they need to claim back more power for themselves in the world beyond the classroom (p. 85).

The foundation of the English-only doctrine was laid in a conference held at Makere University in Uganda in 1961, which paved the way for the emergence of CLT, and was subsequently followed by no- $L 1$ policies, especially in classes taught by native speakers of English. The conference produced the following outcomes (Auerbach, 1993, p. 14):

1. English is best taught monolingually.

2. The ideal teacher of English is a native speaker.

3. The earlier English is taught, the better the results.

4. The more English is taught, the better the results. 
5. If other languages are used too much, standards of English will drop.

Phillipson (1992) argues that the principles adopted in the conference were of ideological nature rather than pedagogical. Auerbach (1993) states that although the five tenets mentioned above never became official, they were adopted as a doctrine that underlay and dominated much of the so-called English language teaching domain around the world. They also became the cornerstones of the hegemony of English worldwide. Auerbach further asserts that language policies in general, especially the ones regarding the imposition of English, are exploited as tools of domination and subordination at a global level.

\section{Methodology}

The study was conducted at a higher education institution in Qatar. This study utilized two questionnaires to assess beliefs and attitudes towards the use of L1 metalanguage in class, one for students and one for teachers. Twenty-six elementary-level students participated in the study as opposed to eight teachers who were all native speakers of Arabic. The justification for recruiting only native-Arabic speaking teachers was based on the rationale that only Arabic-speaking teachers would be able to employ Arabic in class, which was students' L1. This study used a qualitative research design, and the data collected using 5point Likert-scale questions/statements were not subjected to any statistical analysis.

A brief discussion of the student questionnaire follows. Students' responses are presented and the implications of these responses are also analyzed.

\subsection{Student Questionnaire}

The student questionnaire consisted of the following questions:

1. Would you like your teacher to use some Arabic in class?

2. When the teacher uses Arabic in class to teach grammar, does this help you to understand better?

3. In vocabulary teaching, the teacher sometimes gives the Arabic translation of unfamiliar English words. Does this help you understand the meaning of the word better?

Question 1 was geared towards understanding students' attitudes towards the use of Arabic in general. Questions 2 and 3 aimed to gauge students' beliefs and expectations regarding the use of L1 metalanguage in class.

\subsection{Teacher Questionnaire}

The questionnaire designed for teachers consisted of the following statements:

1. For the teaching of grammar, I use the synonyms of metalanguage such as subject, verb, object, adjective, adverb, etc., in Arabic.

2. Students do need their teacher to use Arabic to facilitate comprehension in grammar.

3. For the teaching of vocabulary, I use Arabic words to facilitate comprehension.

4. Students do need their teacher to use Arabic to facilitate comprehension in vocabulary.

5. The use of Arabic should be avoided to expose students to more input in English.

Questions 1 and 2 were on grammar. Question 1 was designed to assess the extent to which the teachers used metalanguage for the teaching of grammar. Question 2 aimed to assess the extent to which teachers could predict how much their students needed the use of Arabic to understand grammar.

Questions 3 and 4 dealt with vocabulary. Question 3 was designed to assess the extent to which the teachers used L1 to teach vocabulary. Question 4 aimed to assess how accurately teachers could predict the extent to which their students needed the use of Arabic to learn vocabulary. It should be noted that the use of L1 in teaching vocabulary is not solely limited to providing the meaning of words in L1; it also involves the teacher's use of metalanguage items such as affix, prefix, suffix, noun, verb, and adjective in L1.

The last item, Question 5, aimed to assess the teachers' reaction to a very controversial statement; whether the teachers believed that they should avoid the use of Arabic to expose students to more input in English.

The questions from the student and teacher questionnaires, as well as the responses and their corresponding percentages, are tabled below. 


\section{Results and Discussion}

Table 1: General Use of Arabic

\begin{tabular}{|c|c|c|}
\hline Yes & Sometimes & No \\
\hline $\mathrm{N}=8(30.7 \%)$ & $N=14(53.8 \%)$ & $N=4(15.3 \%)$ \\
\hline
\end{tabular}

In Question 1, only four students did not prefer Arabic to be used in class. The number of students who answered yes was twice as many as those who answered no. Fourteen students indicated that Arabic should be used sometimes. This suggests that an overwhelming majority of the students (84.6\%) had a positive attitude towards some use of Arabic in class.

Table 2: Use of Arabic for the Teaching of Grammar

2- When the teacher uses Arabic in class to teach grammar, does this help you to understand better?

\begin{tabular}{|c|c|c|c|c|}
\hline always & usually & sometimes & rarely & never \\
\hline$N=13(50 \%)$ & $N=6(23 \%)$ & $N=4(15 \%)$ & $N=1(4 \%)$ & $N=2(8 \%)$ \\
\hline
\end{tabular}

In Questions 2 and 3, the students had to respond to a question based on a five-point scale that ranged from "always" to "never". The majority of the students (73\%) supported the teacher's use of Arabic for the teaching of grammar, whereas $12 \%$ of the students (never $\rightarrow 2+$ rarely $\rightarrow 1=3$ ) seemed to adopt a rather negative attitude. Four students preferred the teacher's occasional use of Arabic by choosing sometimes, which arguably conforms to the principles of judicious use theory proposed by Anderson (1987). With four students sometimes preferring the use of Arabic, a total of 23 students (88\%) displayed a positive attitude towards the use of metalanguage in L1, as opposed to only three students who seemed to be against the use of Arabic for the purposes of facilitating comprehension in grammar.

Table 3: Use of Arabic for Teaching Vocabulary

3- In vocabulary teaching, the teacher sometimes gives the Arabic translation of unfamiliar English words. Does this help you understand the meaning of the word better?

\begin{tabular}{lllll}
\hline always & usually & sometimes & rarely & never \\
\hline $\mathbf{N}=\mathbf{1 7}(\mathbf{6 5 . 3} \%)$ & $\mathbf{N}=\mathbf{4}(\mathbf{1 5 . 4 \% )}$ & $\mathbf{N}=\mathbf{4}(\mathbf{1 5 . 4 \% )}$ & $\mathbf{N}=\mathbf{1}(\mathbf{3 . 8 \% )}$ & $\mathbf{N}=\mathbf{0}$ \\
\hline
\end{tabular}

Students' responses to Question 3 portray an even more positive picture of their attitude towards the use of Arabic in class, especially in terms of being provided the Arabic translation of an unknown word. The students' responses also suggest that they need the use of metalanguage in Arabic slightly more in vocabulary development than in grammar. A total of $80.7 \%$ of the students (always $\rightarrow 17+$ usually $\rightarrow 4=21$ ) seemed to display a very positive attitude towards the use of Arabic for vocabulary learning, while only one student believed that the use of Arabic for vocabulary learning was rarely helpful. Four students stated that being provided the Arabic translation for unknown words was sometimes helpful. This indicates that altogether 25 students (96.1\%) preferred the use of Arabic metalanguage in vocabulary learning, albeit to varying degrees, as opposed to only one student (3.8\%) who stated that she rarely needed the Arabic translation of an unknown vocabulary item.

The findings obtained from the students' responses display a positive picture in terms of their attitude towards the use of Arabic, especially for learning vocabulary, followed by grammar, and to a lesser extent for the general use of Arabic irrespective of language skills such as grammar or vocabulary.

The next section presents the questionnaire for teachers, which is followed by a brief discussion of the implications of teachers' responses.

Table 4: Teachers' Use of Arabic Metalanguage for the Teaching of Grammar

1- For the teaching of grammar, I use the synonyms of metalanguage such as subject, verb, object, adjective, adverb, etc. in Arabic.

\begin{tabular}{llll}
\hline always & usually & sometimes & rarely \\
\hline 5 & 4 & 3 & 2 \\
\hline & $\mathbf{N}=\mathbf{3}(\mathbf{3 7 . 5 \% )}$ & $\mathbf{N}=\mathbf{5}(\mathbf{6 2 . 5 \% )}$ & never \\
\hline
\end{tabular}


The responses to Statement 1 portray a positive picture of the teachers' use of L1 metalanguage for teaching grammar as there were no teachers who had a negative attitude towards the use of Arabic metalanguage. Three teachers (37.5\%) provided the response usually and five teachers (62.5\%) responded sometimes; this suggests that the teachers do use Arabic metalanguage for the purposes of teaching grammar. This finding furthermore suggests that all eight teachers (100\%) tended to use Arabic metalanguage to varying degrees when teaching grammar.

Table 5: Students' Perceptions of Teachers' Use of Arabic for the Teaching of Grammar

2- Students do need their teacher to use Arabic to facilitate comprehension in grammar.

\begin{tabular}{lllll}
\hline always & usually & sometimes & rarely & never \\
\hline 5 & 4 & 3 & 2 & 1 \\
\hline $\mathbf{N}=\mathbf{4}(\mathbf{5 0 \% )}$ & $\mathbf{N}=\mathbf{1}(\mathbf{1 2 . 5 \% )}$ & $\mathbf{N = 3 ( 3 7 . 5 \% )}$ & & \\
\hline
\end{tabular}

As for the teachers' predictions about the extent to which students needed the use of Arabic for grammar, four teachers (50\%) believed that students always needed Arabic to understand grammar concepts in English better. Only one teacher (12.5\%) responded usually, while three teachers (37.5\%) thought that students sometimes needed their teacher to use Arabic for comprehension in grammar. The fact that no teacher chose the options rarely or never showed that all the teachers (100\%) believed that their students needed the use of Arabic to facilitate their students' comprehension of English grammar.

The teachers' responses to Statements 1 and 2 display a positive picture of their attitude towards the use of L1 metalanguage in L2 grammar instruction. Moreover, there seems to be no discrepancy between the frequency with which teachers use Arabic metalanguage in class and their beliefs about the extent to which their students need Arabic metalanguage to learn English grammar. In other words, teachers seem to correctly predict the extent to which their students need L1 metalanguage for grammar learning and respond to that need by adopting the appropriate frequency of the use of L1 metalanguage. This points to an agreement between students' expectations and teachers' pedagogical actions in class.

Statements 3 and 4 below aim to assess teachers' attitudes towards the use of Arabic for vocabulary instruction.

Table 6: Teachers' Use of Arabic Metalanguage for the Teaching of Vocabulary

3- For the teaching of vocabulary, I use Arabic words to facilitate comprehension.

\begin{tabular}{lllll}
\hline always & usually & sometimes & rarely & never \\
\hline 5 & 4 & 3 & 2 & 1 \\
\hline $\mathbf{N}=\mathbf{1}(\mathbf{1 2 . 5 \% )}$ & $\mathbf{N = 1 ( 1 2 . 5 \% )}$ & $\mathbf{N = 5 ( 6 2 . 5 \% )}$ & $\mathbf{N = 1 ( 1 2 . 5 \% )}$ & \\
\hline
\end{tabular}

The teachers' responses to Statement 3 suggest that they are inclined to use less Arabic in vocabulary tasks in comparison to grammar tasks. This, however, does not indicate that they have a negative attitude towards the use of Arabic; by comparison, they seem to use less Arabic in vocabulary instruction. One teacher (12.5\%) stated that s/he rarely used Arabic for vocabulary instruction while no teacher responded never. Three teachers (37.5\%), on the other hand, said that they usually used Arabic for grammar instruction, as opposed to only one (12.5\%) teacher who usually used Arabic for vocabulary instruction. These responses indicate that teachers prefer to use Arabic less in vocabulary instruction. Overall, when teachers' responses according to the three response categories, always, usually, and sometimes are combined (87.5\%), it is obvious that teachers do use Arabic to teach vocabulary, albeit slightly less when compared to grammar.

Table 7: Students' Perception of Teachers' Use of Arabic for the Teaching of Vocabulary

4- Students do need their teacher to use Arabic to facilitate comprehension in vocabulary.

\begin{tabular}{lllll}
\hline always & usually & sometimes & rarely & never \\
\hline 5 & 4 & 3 & 2 & 1 \\
\hline $\mathbf{N}=\mathbf{2}$ (25\%) & $\mathbf{N}=\mathbf{1}(\mathbf{1 2 . 5 \% )}$ & $\mathbf{N}=\mathbf{3} \mathbf{( 3 7 . 5 \% )}$ & $\mathbf{N = 2 ( 2 5 \% )}$ & \\
\hline
\end{tabular}

The responses to Statement 4 depicted a similar picture to teachers' responses to Statement 3. Compared to what they believed regarding their students' needs for the use of Arabic in grammar instruction, the teachers' perceptions were that their students needed less Arabic in vocabulary instruction. That two teachers (25\%) believed that their students rarely needed their teacher to use Arabic to facilitate comprehension in vocabulary, suggests that some teachers were inclined to use Arabic less in vocabulary instruction. This indicates that these teachers believed that their students did not need the use of Arabic for vocabulary instruction as much as they did for grammar instruction. That said, when the number of teachers whose responses were always, usually, and sometimes is combined, six teachers (75\%) still seem to be positively orientated towards the use of Arabic for vocabulary instruction. These findings suggest that the teachers have a slightly more positive attitude towards the use of Arabic for grammar teaching than for vocabulary teaching. 
Table 8: The avoidance of $L 1$ for more exposure to $L 2$

5- $\quad$ The use of Arabic should be avoided to expose students to more input in English.

\begin{tabular}{lllll}
\hline strongly Agree & agree & neutral & disagree & strongly disagree \\
\hline 5 & 4 & 3 & 2 & 1 \\
\hline & $\mathbf{N = 1 ( 1 2 . 5 \% )}$ & $\mathbf{N}=\mathbf{5}(\mathbf{6 2 . 5 \% )}$ & $\mathbf{N = 2 ( 2 5 \% )}$ & \\
\hline
\end{tabular}

The last item in the teacher questionnaire required them to state their opinion on a very controversial issue, which is whether the use of L1 in language classes should be avoided so that students would be exposed to more input in L2. The teachers did not seem to have a strong preference either way. Five teachers remained neutral on this statement, indicating that teachers do not have firm beliefs regarding the issue. Only one teacher (12.5\%) agreed, which suggests that an overwhelming majority of the teachers (87.5\%) were not of the opinion that L1 should be avoided to increase students' exposure to L2 input.

\section{Conclusion}

The overall findings point to the fact that both teachers and students viewed the use of L1 (Arabic in this case) in an L2 class positively. The only minor discrepancy was that some teachers underestimated their students' need for the use of more Arabic for vocabulary instruction. They believed that their students needed the use of Arabic more in grammar instruction whereas students' responses indicated that they needed the use of L1 more in vocabulary instruction. Some teachers' perception that their students needed more Arabic in grammar instruction could originate from their belief that grammar is more complex and challenging, which would consequently require more scaffolding in Arabic. Teachers might feel that the teaching of vocabulary is a simpler process, as even pictures could help teachers to teach vocabulary items. The teachers' relatively diminished use of L1 to teach vocabulary could be attributed to an aim which every single teacher endeavors to achieve, namely to maximize the use of $\mathrm{L} 2$ in class in order to expose his/her students to more input in the target language.

The findings of this study do not echo previous research results that portrayed significant discrepancies between what teachers believed their students knew and what their students actually did. Berry's (1997) study on students' knowledge of metalanguage, Schulz's $(1996,2001)$ studies on students' knowledge of grammar and their need for corrective feedback, McNeill and Lai's study (2005) on teachers' ability to predict their students' difficulties with vocabulary, all yielded similar results. These studies indicated that a substantial mismatch existed between what students knew and what teachers believed their students did.

The findings of this study point to a substantial correlation between teachers' beliefs or predictions about what their students knew and their students' actual knowledge. It should be noted that the teachers who participated in this study were all native Arabic speakers, which might have contributed to such consistency between students' and teachers' attitudes towards the use of L1 metalanguage in L2 classes. It could be argued that native English-speaking teachers would display a different attitude towards the use of L1 metalanguage, especially if they received training with a CLT orientation towards language teaching. Previous research (Moussu \& Llurda, 2008), in fact, reveals that in EFL contexts, native English-speaking teachers are less successful than their non-native counterparts in predicting their students' linguistic needs, as the latter group shares not only their students' L1, but also their social and cultural background.

Further research with native Arabic-speaking teachers would contribute to the validity and reliability of this study. In addition, research that involves native English-speaking teachers in a context where Arabic is the L1 is recommended. This line of research could investigate whether a discrepancy exists between the attitudes of native English-speaking teachers and non-native English-speaking teachers towards the use of L1 metalanguage. It would also help assess the extent to which native and nonnative English-speaking teachers can predict their students' learning difficulties with particular reference to grammar and vocabulary. Such research, in turn, would enable us to implement a comparative analysis of native and non-native Englishspeaking teachers in terms of understanding their students' needs for the use of not only L1 in general, but also for L1 metalanguage. Research on the use of L1 metalanguage in ESL and EFL classes is a promising avenue at a time when monolingual approaches to language teaching are being replaced by bilingual and multilingual approaches that aim to not only teach a second or foreign language, but also to promote crosslinguistic awareness as well as metalinguistic awareness.

The findings obtained from this study suggest that $\mathrm{L} 1$ still has a facilitative role in learning, in contrast to the prevailing dogma of the 1970s and 1980s. According to this study, the use of L1 metalanguage in an L2 class seems to be welcomed and appreciated by the students, who consistently report that the use of L1 has a positive impact on their learning.

The use of English-only practices can be justified to some extent if and when the teacher does not speak the students' L1 or when a class is full of students with diverse linguistic backgrounds, especially in ESL contexts. Ellis (2012) proposes that a 
fundamental requirement to gain entry into teacher training programs such as CELTA ${ }^{2}$ and DELTA ${ }^{3}$, is that candidates should have multilingual skills. This suggests that a monolingual teacher should not be able to make it into a teacher training program unless s/he speaks at least two languages. If this is not the case, then Ellis argues that these individuals should be required to study a second language before embarking on their career in teaching English.

It is important to note that teachers trained according to a monolingual orientation to teaching an L2 are very likely to lack crosslinguistic and metalinguistic awareness, which might place their students at a severe disadvantage.

It is difficult to understand policies and practices that reject the use of L1 in class when classroom research consistently points to the cognitive advantages of using L1 (Swain, Lapkin, Knouzi, Suzuki \& Brooks, 2009).

This is indeed a dilemma which is very likely to have a major detrimental impact on students' learning. What is truly unfortunate is our tendency to ignore students' voices when we constantly preach that our classroom practices should be based on the principles of student-centeredness. Within this scenario, our claims that we are student-centred teachers do not go beyond being limited to just a slogan. The term "slogan" reminds me of Widdowson's following argument with which I would like finalize this paper.

Although we as TESOL professionals say that we should not make changes for their own sake, we do make them for the sake of demonstrating that we are still dynamic, and for this purpose even the appearance of change will do. And this is why old ideas keep coming back with the veneer of novelty. But we do not want changes to be too disruptive either. It is preferable for our sense of security that they should be easily assimilated, and one way of managing this is to reduce ideas to simple terms that sound good: comprehensible input, natural learning, authentic language, real English. These become a kind of catchphrase currency whose value is taken for granted without further enquiry. And thus we become slogan prone (1998, p. 705).

\section{References}

[1] Atkinson, D. (1987). The mother tongue in the classroom: a neglected resource? ELT Journal, 41(4), 241-247.

[2] Auerbach, E.R. (1993). Reexamining English Only in the ESL Classroom. TESOL Quarterly, 27(1), 9-32.

[3] Berry, R. (1997). Teachers' awareness of learners' knowledge: The case of metalinguistic terminology. Language Awareness, 6, $136-146$.

[4] Bialystok, E. (2009). Bilingualism: The good, the bad, and the indifferent. Bilingualism: Language and Cognition, 12, 3-11. doi: $10.1017 / \mathrm{S} 1366728908003477$.

[5] Burden, P. (2000). The use of the students' mother tongue in monolingual English conversation classes at a Japanese university. The Language Teacher, 24(16), 5-10.

[6] Butzkamm, W. (2003). We only learn language once. The role of the mother tongue in FL classrooms: Death of a dogma. Language Learning Journal, 28, 29-39.

[7] Chomsky, N. (1965). Syntactic structures. The Hague: Mouton.

[8] Collingham, M. (1988). Making use of students' linguistic resources. In S. Nicholls \& E. Hoadley-Maidment (Eds.), Current issues in teaching English as a second language to adults (pp. 81-85). London: Edward Arnold.

[9] Cook, V. (2001). Using the First Language in the Classroom. Canadian Modern Language Review, 57(3), 402-423. DOI: 10.3138/cmlr.57.3.402

[10] Cummins, J. (1981). The role of primary language development in promoting educational success for language minority students. In California State Department of Education (Ed.), Schooling and language minority students: A theoretical framework. (pp. 3-49). Los Angeles: California State University, Evaluation, Dissemination and Assessment Center.

[11] Duff, A. (1989). Translation. Oxford: Oxford University Press.

[12] Ellis, E. M. (2012). Language awareness and its relevance to TESOL. University of Sydney. $\quad$ Papers in TESOL, 7, 1-23.

[13] Garcia, E. (1991). Education of linguistically and culturally diverse students: Effective instructional practices. Santa Cruz, CA: National Center for Research on Cultural Diversity and Second Language Learning.

[14] Hammarberg, B. (2010). The languages of the multilingual: Some conceptual and terminological issues. International Review of Applied Linguistics, 48, 91-104.

[15] Hawkins, E. (1999). Foreign Language Study and Language Awareness. Language Awareness, 8(3-4), 124-142.

[16] Horst, M., White, J. \& Bell, P. (2010). First and second language knowledge in the language classroom. International Journal of Bilingualism, 14(3), 331-349.

[17] Jessner, U. (2008). Teaching third languages: Findings, trends and challenges. Language Teaching, 41, 15-56.

[18] Krashen, S. (1982). Principles and practice in second language learning acquisition. Oxford: Pergamon.

[19] Laufer, L., Meara, P., \& Nation, P. (2005). Ten best ideas for teaching vocabulary. The language Teacher, 29(7), 3-10.

[20] Levine, G. S. (2003). Student and instructor beliefs and attitudes about target language use, first language use, and anxiety: report of a questionnaire study. The Modern Language Journal, 87, 343-364.

[21] Long, M. (1991). Focus on form: A design feature in language teaching methodology. In K. de Bot, R. Ginsherg, \& Kramsch, C. (Eds.), Foreign Language Research in Cross-cultural Perspective. Pp. 39-52. Amsterdam: John Benjamin.

\footnotetext{
${ }^{2}$ CELTA is an initial teacher training qualification for teaching English as a second or foreign language (ESL and EFL).

${ }^{3}$ DELTA is an English language teaching (ELT) qualification for experienced Teachers of English as a Foreign Language (TEFL) and Teachers of English to Speakers of Other Languages (TESOL)
} 
[22] McNeill, A., \& Lai, T. K. H. (2008, June 26-29). Teachers' awareness of the English lexical System [Paper presentation]. The 9th ALA Conference, University of Hong Kong, Hong Kong.

[23] Miles, R. (2004). Evaluating the Use of L1 in the English language Classroom [Unpublished master's dissertation]. University of Birmingham.

[24] Moussu, L., \& Llurda, E. (2008). Non-native English-speaking English language teachers: History and research. Language teaching, 41(3), 315348.

[25] Nation, P. (2003). The role of the first language in foreign language learning. Asian EFL Journal, 5(2), 1-8.

[26] Nazary, M. (2008). The role of L1 in L2 acquisition: attitudes of Iranian university students. Novitas-ROYAL, 2(2), $138-153$.

[27] Phillipson, R. (1992). Linguistic imperialism. Oxford: Oxford University Press.

[28] Phipps, S. \& Borg, S. (2009). Exploring tensions between teachers' grammar teaching beliefs and practices. System, 37(3), 380-390.

[29] Prodromou, L. (2002). From mother tongue to other tongue. Teaching English. https://www.teachingenglish.org.uk/article/mother-tongueother-tongue.

Retrieved April 1, 2021.

[30] Schulz, R. A. (1996). Focus on form in the foreign language classroom: Students' and teachers' views on error correction and the role of grammar. Foreign Language Annals, 29, 343-364.

[31] Schulz, R. A. (2001). Cultural differences in student and teacher perceptions concerning the role of grammar teaching and corrective feedback: USA-Colombia. Modern Language Journal 85, 244-258.

[32] Schweers, W. (1999). Using L1 in the L2 classroom. English Teaching Forum, 37(2), 6-9.

[33] Simard, D. (2004). Using diaries as a way to promote metalinguistic reflection among elementary school students. Language Awareness, 13, 34-48.

[34] Stapa, S.H. \& Majid, A.H.A. (2006). The use of first language in developing ideas in second language writing. American Journal of Social Issues \& Humanities 2 (3), 148-151.

[35] Swain, M., Lapkin, S., Knouzi, I., Suzuki, W., \& Brooks, L. (2009). Languaging: University students learn the grammatical concept of voice in French. The Modern Language Journal, 93(1), 5-29. doi:10.1111/j.1540-4781.2009.00825.x

[36] Tang, J. (2002). Using L1 in the English Classroom. English Teaching Forum, 40(1), 36-44.

[37] Tokowicz, N. \& MacWhinney, B. (2005). Implicit and explicit measures of sensitivity to violations in second language grammar: An eventrelated potential investigation. SSLA, 27(2), 173-204.

[38] Widdowson, H. G. (1998). Context, Community, and Authentic Language. TESOL Quarterly, 32(4), 705-716.

[39] Zacharias, N.T. (2004). Teachers' beliefs about the use of the students' mother tongue: A survey of Tertiary English Teachers in Indonesia. EA JOURNAL, 22(1), 23-37.

[40] Zhang, M. X. (1998). TESL: The Crucial Role of Formal and Explicit Instruction and Learners' Prior Knowledge: An Example in Learners of Chinese Background. [S.I.]: Distributed by ERIC Clearinghouse. 